\section{8. 九州の国有林における振動障害の長期予後}

$\bigcirc$ 二塚 信 (熊本大・医・公乑衛生) 九州の国有林で1955年から 1982 年まで尃属的に千工 ンソーを使用し，レイノー現象（以下VWF）を発症し た496名を対象に1997年に而接調查をおこない現浖を 把握した。

その結果，488名の現況が把握され，退職者は481名 (96.6\%) で死亡者は 124 名 $(25.4 \%)$ であった.VWF の消長が確認された 377 名の症度別の予後を，チェンソ 一の使用中止 25 年後のVWFの残存率でみると，ス卜 ックホルム症度分類 I (29名) で17\%，II（268名） で $53 \% ，$ III（73名）で $88 \%$ と，振動曝露中此時の症度 に依存していた。VWFの消裉は瀑露中止後 5 年以内 81 例 $(50.9 \%), 10$ 年以内で 115 例 $(72.3 \%)$, 他方 15 年 以後に消煺をみた例も 17 例 $(10.7 \%)$ ，みられた。予後 の良好例と不良例の比較を行ったところ，年齢（加齢）, 喫煙，振動曝露量に差はみられなかった。難治例（15 例）について，熊大神経内科の協力を得て病態生理学的 検索を行ったところ，自律神経機能異常を示すものが目 立った。

\section{9. 北九州市における産業廃棄物処理の現状}

○天野松男（(财）佂和会) [はじめに］北九州市における産業廃率物処理の現状を 知るために「廃掃法」に基づき産業廃菄物処理業および 特別管理産業廃车物処理業として北九州市長の許可を受 けた業者名簿を分析した。

[資料と方法］樂者名簿は，北九州市がインターネット ホームページに揭載しているもの（中閒処理業者）をダ ウンロードして得た。

[結果］産業廃童物または特別管理産業廃亲物の中間処 分許可を受けている者は，それぞれ，87業者，18業者 であった（1)廃プラスチック類，ゴムくず等の一般産業 廃卒物はほとんど燒却処分されて㧍り，その事業者数は 26 社であった。(2)特別管理産業廃髙物も焼却処分で許 可を受けている者が多く 10 社であった。

[まとめ］産業廃亲物は多くの紫者が焼却処分で許可を 受けていた。それだけ㜔却される廃裹物の量も多いもの と思われ，市民への健康影響が懸念された。

\section{0. オフィスにおける空間分煙}

○秋山 泉 ${ }^{1}$, 大和 浩 $^{1}$, 溝上 哲也 ${ }^{1}$, 森本泰夫 ${ }^{1}$ 大神 明 $^{1}$, 大薮貴子 ${ }^{1}$, 保利 $\cdots^{2}$, 田中勇武 ${ }^{1}$ (産業医科大学 ${ }^{1}$ 産紧生態科学研究所, ${ }^{2}$ 産業保健学部) 室内の一角の応接セットが喫煙場所として定められて いた事務室の分煙対策の改善について検討した。ここで は排気装置も煙搪散防止のための対策もとられておら ず，環境たばこ煙は室内全体を污染していた。この喫煙
場所を四うように天井から垂れ幕と防炎スクリーン（透 明）を設置し，スクリーン直下に本棚を眍置して煙拡散 防止対策を行った。この喫煙コーナー（横 $3 \mathrm{~m} \times$ 奥 $4 \mathrm{~m}$ $\times$ 高 $2.7 \mathrm{~m}$ ）内の空の一部を切り取り排気装置 $\left(33 \mathrm{~m}^{3} /\right.$ 分）を設置した。改善後では，禁瞥区域に招ける室内粉 じん濃度は明らかに改善した。また，1日の総喫煌本数 より求めた適切な排気風量を設定したことにより，コー ナー内の空気環境は良好な状態に保つことができた，透 明のスクリーンを用いたことにより，窒内の零四気を損 なうこともなかった。必要であった䞆用は48万円であ つた．效果が高く，かつ灾価な空間分煙対策であること が請められた。

\section{1. 慢性閉塞性肺疾患死亡率と気温変化との関連}

○新城正紀（沖縄県方看護大） 田中英夫（大阪府立成人病センター） 川㤗由利（大阪がん予防センター） 川妻厚子（大阪府曾田林保健所） 下地塞夫（沖縄県衛生環境研究所） 森田俊楌（沖縄県福祉保健部） 沖縄の慢性閉寒性肺疾患（COPD）の死亡率は全国の 中で高率である。COPDの発症と悪化に関連する各種 のアレルゲンや大気中の浮遊物質の暴露は，その地域の 気温や季節によっても変化すると思われる，そこで，洲 縄の月別 COPD死亡摔と月別平均気温との関連を調查 し，気温較差の大きい大阪の成績と比較した。死し情報 は，1992～96 年の沖縄県と大阪拊の人口動態統計を用 い，45歳から 84:歳の男女を対象とし，COPD（ICD9: $490 \sim 496$, ICD10: J40 J47）の月别年䶔調整死亡率を 算出した。気温情報は，気象庁の月別地上気爱微測值を 用いた。沛縄のCOPD死亡率は全ての月で大阪より澶 く，特に春から初夏にかけて，相対的に高かった，沖縄 の平均気温の最低月 $\left(2\right.$ 月, $\left.16.4{ }^{\circ} \mathrm{C}\right)$ と最高月 $(7$ 月,

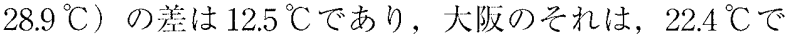
あった。沖縄の月別 COPD死亡率は，月别斗均気温と の間に有意な相関 $(r=-0.676, p<0.01)$ が認められ た。

\section{2. 職業衛生管理における健康教育の意義}

$\bigcirc$ 李 楓 ${ }^{1}$, 呉静英 ${ }^{1}$, 李達飛 ${ }^{2}$, 李黎軍 ${ }^{2}$ $\left({ }^{1}\right.$ 上海医科大学健䐂教育捧座,

2 上海打閵行区衛生防疫センター) 【日的】本研究は，「上海市に㧍ける職業病予防条例」が 施行された 1 年後の効果を評価することを目的とした。 【方法】上海市内の有毒・有害物取扱企業 307 社に対古 る現場調查の実施時に，これらの企涩の作策者，管理者 並びに産業保健識員に対して産業衛生専門知禨および 「識業病予防条例」の教育を行った。教育前後の作業現 